\title{
Analisis Mutu Keripik Tempe Berdasarkan Cara Perekatan dan Ketebalan Pengemas Selama Penyimpanan
} Quality Analysis of Tempeh Chips based on the Gluing Method and Packaging Thickness during
Storage

\author{
Kavadya Syska ${ }^{1 *}$, Ropiudin ${ }^{2)}$ \\ ${ }^{1)}$ Universitas Nahdlatul Ulama Purwokerto, Program Studi Teknologi Pangan, Indonesia \\ ${ }^{2)}$ Universitas Jenderal Soedirman, Program Studi Teknik Pertanian, Indonesia \\ *email: syska.kavadya@gmail.com
}

Received: 06/06/20; Revised: 29/06/20; Accepted: 29/06/20

\begin{abstract}
Abstrak
Keripik tempe adalah salah satu makanan khas di Indonesia. Tujuan penelitian ini yaitu: mengetahui pengaruh cara perekatan dan ketebalan pengemas terhadap mutu keripik tempe, dan mengetahui umur simpan keripik tempe berdasarkan cara perekatan pengemas dan ketebalan pengemas. Faktor yang diteliti yaitu, cara perekatan: stapler, lilin, dan sealer, jenis pengemas: plastik polipropilen $0,07 \mathrm{~mm}$ dan plastik polipropilen $0,04 \mathrm{~mm}$, dan lama penyimpanan: 10 hari, 20 hari, dan 30 hari. Hasil penelitian menunjukkan bahwa keripik tempe dengan kemasan plastik polipropilen 0,07 mm dan perekat sealer memiliki mutu paling baik. Selama penyimpanan terjadi peningkatan kadar air, kadar asam lemak bebas, dan kadar peroksida serta terjadi penurunan semua variabel sensorik, tetapi keripik tempe kemasan plastik polipropilen 0,07 $\mathrm{mm}$ dengan perekat sealer mampu mempertahankan mutu keripik tempe sampai hari ke-30, sedangkan perlakuan lainnya hanya mampu sampai hari ke-20.
\end{abstract}

Kata kunci: analisis pangan, kemasan, keripik tempe, mutu, penyimpanan

\begin{abstract}
Tempeh chips are one of the typical foods in Indonesia. The purposes of this research are: to determine the effect of the way of gluing the packaging and thickness of the packer to the quality of tempeh chips, and to know the shelf life of tempeh chips to the way of gluing the packaging and packaging thickness. Factors studied of gluing methods were: stapler, wax, and sealer, type of packaging: $0.07 \mathrm{~mm}$ polypropylene plastic and $0.04 \mathrm{~mm}$ polypropylene plastic, and storage time: 10 days, 20 days, and 30 days. The results showed that tempeh chips with $0.07 \mathrm{~mm}$ polypropylene plastic packaging and sealer adhesives had the best quality, during storage there was an increase in water content, free fatty acid levels, and peroxide levels as well as a decrease in all sensory variables, and tempeh chips in polypropylene plastic packaging. $0.07 \mathrm{~mm}$ with sealer adhesive is able to maintain the quality of tempeh chips until the 30th day, while other treatments are only capable until the 20th day.
\end{abstract}

Keywords: food analysis, packaging, quality, storage, tempeh chips 


\section{Analisis Mutu Keripik Tempe Berdasarkan Cara Perekatan dan Ketebalan Pengemas selama Penyimpanan}

\section{PENDAHULUAN}

Tempe merupakan makanan tradisional yang sangat digemari oleh masyarakat karena selain rasanya yang gurih dan enak, juga karena gizi yang dikandungnya. Tempe merupakan hasil fermentasi kedelai oleh kapang Rhizopus sp, yang membentuk massa yang padat dan kompak (Shurtleff \& Aoyagi, 2001). Umur simpan tempe dalam bentuk segar relatif pendek dan umur simpan yang pendek dapat diatasi dengan usaha pengolahan tempe antara lain dibuat keripik tempe (Shockey \& Shockey, 2019).

$\begin{array}{rrr}\text { Mindarti } & \text { (2016) UMKM } & \text { keripik } \\ \text { tempe telah } & \text { berkontribusi } & \text { dalam }\end{array}$
meningkatkan tingkat ekonomi lokal dan telah memberikan kesempatan kerja bagi perempuan. Keripik tempe khas Purwokerto, Jawa Tengah memiliki bentuk yang tebal namun teksturnya tetap renyah. Hal ini yang membedakan dengan keripik tempe dari daerah lain seperti Bandung, Madiun, dan Malang. Oleh karena itu keripik tempe Purwokerto ini perlu dikembangkan dan ditingkatkan mutunya. Menurut Kurniawati $d k k$. (2019) hal ini sehubungan dengan produk berbasis tempe yang mudah mengalami penurunan mutu.

Perubahan yang terjadi pada keripik tempe dapat diminalisir dengan mengurangi kontak antara produk dengan faktor yang dapat memicu terjadinya kerusakan yaitu: oksigen, uap air dan cahaya, suhu, dan kelembaban ruang penyimpanan (Fiorino dkk., 2019; Aguilar \& Carvajal-Millan, 2019). Kontak antara produk dengan faktor tersebut dapat dikurangi dengan cara pengemasan yang benar (Aguilar \& Carvajal-Millan, 2019). Umur simpan keripik 4-6 minggu dapat dicapai ketika keripik disimpan pada suhu $21{ }^{\circ} \mathrm{C}$ (Marcus, 2019).
Kenyataan di pasaran, produsen keripik tempe belum sepenuhnya memperhatikan faktor-faktor yang dapat mengakibatkan kerusakan produknya (Barus dkk., 2017; Huang dkk., 2019; Erkan dkk., 2020). Produsen masih menggunakan metode manual dalam proses pengemasannya, seperti stapler sebagai bahan perekat kemasan, meskipun terdapat alat perekat lain, yaitu sealer.

Stapler sebagai perekat kemasan mempunyai beberapa kekurangan yang dapat menurunkan penerimaan konsumen terhadap produk tersebut (Piergiovanni \& Limbo, 2016). Kekurangan stapler sebagai perekat kemasan, antara lain menimbulkan bekas berupa lubang pada kemasan sehingga kemungkinan udara dapat keluar masuk ke dalam kemasan, menimbulkan ketidaknyamanan pada konsumen karena sulit pada proses pembukaan kemasan dan dapat menimbulkan luka atau kerusakan pada kuku dan jari tangan, dapat bercampur dengan produk dan dapat termakan oleh konsumen sehingga dapat membahayakan jiwa konsumen (Piergiovanni \& Limbo, 2016).

Plastik yang umum digunakan untuk mengemas makanan ringan adalah plastik polipropilen (PP) (Grumezescu \& Holban, 2018). Plastik polipropilen merupakan jenis plastik yang ringan, mudah dibentuk, lebih kaku dari polietilen dan tidak mudah sobek (Bernaldo de Quirós $d k k$., 2019). PP juga tahan terhadap asam kuat, basa, dan minyak. Sifat-sifat yang dimiliki oleh PP, sangat cocok untuk pengemasan keripik tempe yang memiliki bentuk persegi yang tipis dan memiliki siku-siku yang runcing serta banyak mengandung minyak (Singh $d k k .$, 2017). PP memiliki ketebalan yang beragam yang berpengaruh terhadap permeabilitas uap air (Duan dkk., 2020). Semakin tebal kemasan untuk jenis yang 


\section{Analisis Mutu Keripik Tempe Berdasarkan Cara Perekatan dan Ketebalan Pengemas selama Penyimpanan}

sama, maka semakin rendah permeabilitasnya terhadap uap air (Cirillo $d k k ., 2018)$.

Beberapa riset terkait dengan kemasan dan penyimpanan produk pangan telah diteliti oleh Furqon, $d k k$. (2016) mengenai pengaruh jenis pengemas dan lama penyimpanan terhadap mutu produk nugget gembus, Herawati, dkk. (2017) mengkaji pendugaan umur simpan keripik pisang salut cokelat "purbarasa" kemasan polipropilen berdasarkan angka TBA dengan Metode Aslt Model Arrhenius, Warsiki \& Damanik (2012) mengkaji perubahan mutu dan umur simpan sup daun torbangun (Colues amboinicus Lour) dalam kemasan, dan Roreng, dkk. (2016) mengkaji mutu mikrobiologis drupa buah merah (Pandanus conoideus Lamk.) pada berbagai jenis kemasan selama penyimpanan.

Berdasarkan data-data penelitian sebelumnya, maka perlu dikaji pengaruh dari penggunaan stapler, lilin, dan sealer terhadap mutu produk selama penyimpanan khususnya pada produk keripik tempe. Jariyah $d k k$. (2015) menyatakan bahwa perlu adanya terobosan baru yang lebih inovatif, mengingat di daerah perajin tempe sangat strategis untuk dikembangkan. Tujuan penelitian ini yaitu: mengetahui pengaruh cara perekatan pengemas dan ketebalan pengemas terhadap mutu keripik tempe, dan mengetahui umur simpan keripik tempe berdasarkan cara perekatan pengemas dan ketebalan pengemas.

\section{METODE PENELITIAN.}

Bahan yang digunakan yaitu: keripik tempe yang baru digoreng oleh UMKM Keripik Tempe di Purwokerto, plastik polipropilen $0,07 \mathrm{~mm}$, plastik polipropilen
0,04 mm, perekat stapler, sealer, lilin, dan bahan kimia seperti phenolphthalein, etanol, $\mathrm{NaOH}$, asam asetat, $\mathrm{KI}, \mathrm{Na}_{2} \mathrm{~S}_{2} \mathrm{O}_{3}$, larutan pati, dan kloroform.

\section{Metodologi Penelitian}

Metode penelitian yang digunakan yaitu metode eksperimental, dengan rancangan acak. Faktor yang dicoba ada tiga macam yaitu:

a) Cara Perekatan Pengemas (K)

1. Perekatan menggunakan Stapler (K1)

2. Perekatan menggunakan Lilin (K2)

3. Perekatan menggunakan Sealer (K3)

b) Ketebalan Pengemas (L)

1. Plastik Polipropilen 0,07 mm (L1)

2. Plastik Polipropilen 0,04 mm (L2)

c) Waktu Penyimpanan (M)

1. Waktu Penyimpanan 10 hari (M1)

2. Waktu Penyimpanan 20 hari (M2)

3. Waktu Penyimpanan 30 hari (M3)

Berdasarkan perlakuan tersebut dibuat rancangan percobaan faktorial dan diperoleh 18 kombinasi perlakuan sebagai berikut:

\begin{tabular}{|c|c|c|}
\hline K1L1M1 & K2L1M1 & K3L1M1 \\
\hline K1L1M2 & K2L1M2 & K3L1M2 \\
\hline K1L1M3 & K2L1M3 & K3L1M3 \\
\hline K1L2M1 & K2L2M1 & K3L2M1 \\
\hline K1L2M2 & K2L2M2 & K3L2M2 \\
\hline K1L2M3 & K2L2M3 & K3L2M3 \\
\hline
\end{tabular}

Masing-masing perlakuan diulang 3 kali sehingga diperoleh 54 unit percobaan.

Keripik tempe yang diperoleh dari salah satu UKM keripik tempe di Purwokerto, Jawa Tengah sebanyak 540 buah dengan ukuran keripik tempe (panjang x lebar x tebal) yaitu $6,5 \mathrm{~cm}, 9$ $\mathrm{cm}$, dan $0,1 \mathrm{~cm}$. Keripik tempe dikemas dalam satu jenis pengemas yang sama berukuran panjang $35 \mathrm{~cm}$ dan lebar $15 \mathrm{~cm}$, dengan ketebalan 0,07 $\mathrm{mm}$ dan 0,04 $\mathrm{mm}$. Keripik tempe dikemas dengan 3 macam 


\section{Analisis Mutu Keripik Tempe Berdasarkan Cara Perekatan dan Ketebalan Pengemas selama} Penyimpanan

perekat yaitu stapler, sealer, dan lilin serta disimpan dalam jangka waktu yang telah ditentukan. Satu kemasan berisi 10 buah keripik tempe. Selanjutnya, masing-masing perlakukan dianalisis kadar air, dan kadar asam lemak bebas.

\section{Analisis Produk}

\section{Analisis Kadar Air (Nielsen, 2017)}

Botol timbang dikeringkan dalam oven pada suhu $105{ }^{\circ} \mathrm{C}$ selama 30 menit, kemudian didinginkan di dalam desikator dan ditimbang bobotnya (A). Sampel yang telah dihaluskan dimasukkan ke dalam botol timbang kemudian ditimbang bobotnya (B). Botol timbang yang telah berisi sampel dikeringkan di dalam oven pada suhu $100-105{ }^{\circ} \mathrm{C}$ selama 3-5 jam, kemudian didinginkan di dalam desikator dan ditimbang bobotnya (C). Pengeringan diulangi sampai mencapai bobot konstan. Kadar air dihitung menggunakan persamaan 1 (Aguilar \& Carvajal-Millan, 2019).
Kadar air $(\% \mathrm{bb})=\frac{B-C}{B-A} X 100 \%$

\section{Analisis Asam Lemak Bebas (Nielsen,} 2017)

Sebanyak 28,2 $\pm 0,2 \mathrm{~g}$ sampel ditimbang dan dimasukkan ke dalam erlemeyer. Selanjutnya ditambahkan 50 $\mathrm{mL}$ etanol dan $2 \mathrm{~mL}$ phenolphthalein konsentrasi $1 \%$. Titrasi dengan larutan $\mathrm{NaOH}$ sampai warna merah jambu tercapai dan tidak hilang selama 30 detik.

\section{Uji Organoleptik}

Uji organoleptik dilakukan dengan memberikan skor pada masing-masing variabel, yaitu: aroma, ketengikan, tekstur, rasa, dan kesukaan (Hollowood $d k k$., 2018; Zhong \& Wang, 2019). Kriteria analisis organoleptik dapat dilihat pada Tabel 1. Kriteria analisis organoleptik pada Tabel 1 dilakukan dengan menggunakan pendekatan skala atau skor yang dihubungkan dengan desnripsi tertentu dari atribut mutu produk (Hollowood, $d k k$., 2018 dan Meilgaard, $d k k$., 2016).

Tabel 1. Kriteria Analisis Organoleptik

\begin{tabular}{cccccc}
\hline \multirow{2}{*}{ Skor } & \multicolumn{5}{c}{ Kriteria } \\
\cline { 2 - 6 } & Aroma & Ketengikan & Tekstur & Flavor & Kesukaan \\
\hline 1 & Tidak & Sangat & Tidak & Tidak & Tidak \\
& harum & tengik & renyah & enak & suka \\
2 & Agak & Tengik & Agak & Agak & Agak suka \\
& harum & & renyah & enak & \\
3 & Harum & Agak tengik & Renyah & Enak & Suka \\
4 & Sangat & Tidak & Sangat & Sangat & Sangat \\
& harum & tengik & renyah & enak & suka \\
\hline
\end{tabular}

\section{Analisis Data}

Analisis data menggunakan uji $\mathrm{F}$ (sidik ragam) pada taraf 5 persen untuk variabel kimiawi (Alkarkhi \& Alqaraghuli, 2019). Apabila berpengaruh nyata dilanjutkan dengan Uji Jarak Berganda Duncan (DMRT) pada taraf 5 persen (Alkarkhi \& Alqaraghuli, 2019). Variabel inderawi yaitu uji organoleptik dianalisis dengan uji Friedman (Hollowood $d k k$., 2018; Meilgaard dkk., 2016; Zhong \& Wang, 2019).

\section{HASIL DAN PEMBAHASAN \\ Kadar Air}

Kadar air keripik tempe pada masing-masing perlakuan selama penyimpanan cenderung mengalami 


\section{Analisis Mutu Keripik Tempe Berdasarkan Cara Perekatan dan Ketebalan Pengemas selama Penyimpanan}

peningkatan yang dapat dilihat pada Tabel

2. Peningkatan kadar air ini diduga karena berhubungan dengan sifat higroskopis yang dimiliki keripik tempe sebagai produk kering atau berkadar air rendah. Produk yang higroskopis cenderung lebih mudah menyerap uap air dari luar pengemas. Semakin rendah kadar air suatu bahan maka semakin mudah bahan tersebut menyerap uap air. Bahan yang mempunyai kadar air rendah apabila disimpan dalam kondisi yang lembab, akan menyerap air dan udara di sekitarnya sehingga akan menyebabkan peningkatan kadar air (Alkarkhi \& Alqaraghuli, 2019).

Tabel 2. Pengaruh jenis perekat, ketebalan pengemas, dan waktu penyimpanan terhadap kadar air

\begin{tabular}{ccc}
\hline No. & $\begin{array}{l}\text { Interaksi } \\
\text { Perlakuan }\end{array}$ & $\begin{array}{l}\text { Rata-rata Kadar Air } \\
\text { (\%bb) }\end{array}$ \\
\hline 1 & K1L1M1 & $2,4870 \mathrm{~d}$ \\
2 & K1L1M2 & $2,2223 \mathrm{~d}$ \\
3 & K1L1M3 & $9,7663 \mathrm{a}$ \\
4 & K1L2M1 & $3,0213 \mathrm{~d}$ \\
5 & K1L2M2 & $1,6860 \mathrm{~d}$ \\
6 & K1L2M3 & $3,3357 \mathrm{~cd}$ \\
7 & K2L1M1 & $2,6710 \mathrm{~d}$ \\
8 & K2L1M2 & $3,0433 \mathrm{~d}$ \\
9 & K2L1M3 & $5,3997 \mathrm{bcd}$ \\
10 & K2L2M1 & $2,0507 \mathrm{~d}$ \\
11 & K2L2M2 & $3,0557 \mathrm{~d}$ \\
12 & K2L2M3 & $7,2633 \mathrm{abc}$ \\
13 & K3L1M1 & $2,6550 \mathrm{~d}$ \\
14 & K3L1M2 & $7,1597 \mathrm{abc}$ \\
15 & K3L1M3 & $4,5930 \mathrm{~cd}$ \\
16 & K3L2M1 & $3,5313 \mathrm{~cd}$ \\
17 & K3L2M2 & $9,2253 \mathrm{ab}$ \\
18 & K3L2M3 & $10,8043 \mathrm{a}$ \\
\hline
\end{tabular}

Banyaknya uap air yang diserap oleh keripik tempe dipengaruhi oleh sifat permeabilitas yang dimiliki oleh plastik polipropilen. Plastik polipropilen memiliki permeabilitas terhadap uap air yang rendah dan permeabilitas terhadap gas oksigen sedang. Menurut Hollowood dkk. (2018) Polipropilen memiliki daya tembus terhadap oksigen sebesar 23 x 1010 $\mathrm{cm}^{3} / \mathrm{cm}^{2} / \mathrm{mm} / \mathrm{s} / \mathrm{cmHg}$, daya tembus terhadap uap air sebesar 680 x 1010 $\mathrm{cm}^{3} / \mathrm{cm}^{2} / \mathrm{mm} / \mathrm{s} / \mathrm{cmHg}$. Walaupun permeabilitas terhadap uap air rendah tetapi semakin lama penyimpanan, uap air yang terserap akan semakin banyak.

Berdasarkan data, interaksi perekat stapler dengan PP 0,04 mm merupakan komposisi terbaik untuk mempertahankan kadar air. Interaksi perekat stapler dengan plastik polipropilen $0,04 \mathrm{~mm}$ memiliki nilai kadar air paling rendah, hal ini diduga karena plastik PP 0,04 mudah dilipat dan lipatan yang dihasilkan cukup rapih sehingga rekatan yang dihasilkan lebih baik dibandingkan dengan plastik yang lebih tebal.

\section{Kadar Asam Lemak Bebas}

Hasil analisis ragam menunjukkan bahwa perlakuan ketebalan pengemas memberikan pengaruh yang sangat nyata terhadap kadar asam lemak bebas, disajikan dalam Tabel 3. Hal ini diduga karena perbedaan permeabilitas terhadap uap air dan gas yang dimiliki oleh masingmasing kemasan. Semakin tebal suatu kemasan maka permeabilitas terhadap uap air dan gas semakin rendah.

Tabel 3. Pengaruh jenis perekat, ketebalan pengemas, dan waktu penyimpanan terhadap kadar asam lemak bebas

\begin{tabular}{ccc}
\hline No. & $\begin{array}{c}\text { Interaksi } \\
\text { Perlakuan }\end{array}$ & $\begin{array}{c}\text { Rata-rata Kadar } \\
\text { Asam Lemak Bebas } \\
\text { (\%FFA) }\end{array}$ \\
\hline 1 & K1L1M1 & $6,6943 \mathrm{ef}$ \\
2 & K1L1M2 & $6,9300 \mathrm{def}$ \\
3 & K1L1M3 & $8,9143 \mathrm{abc}$ \\
4 & K1L2M1 & $6,1543 \mathrm{f}$ \\
5 & K1L2M2 & $9,4577 \mathrm{ab}$ \\
6 & K1L2M3 & $7,6670 \mathrm{bcdef}$ \\
7 & K2L1M1 & $5,9050 \mathrm{f}$ \\
8 & K2L1M2 & $8,7460 \mathrm{abcd}$ \\
9 & K2L1M3 & $7,7823 \mathrm{bcdef}$ \\
10 & K2L2M1 & $7,7780 \mathrm{bcdef}$
\end{tabular}




\begin{tabular}{ccc}
\hline No. & $\begin{array}{c}\text { Interaksi } \\
\text { Perlakuan }\end{array}$ & $\begin{array}{c}\text { Rata-rata Kadar } \\
\text { Asam Lemak Bebas } \\
\text { (\%FFA) }\end{array}$ \\
\hline 11 & K2L2M2 & $9,9443 \mathrm{a}$ \\
12 & K2L2M3 & $8,9283 \mathrm{abc}$ \\
13 & K3L1M1 & $8,1823 \mathrm{abcde}$ \\
14 & K3L1M2 & $6,8657 \mathrm{def}$ \\
15 & K3L1M3 & $6,8677 \mathrm{def}$ \\
16 & K3L2M1 & $7,4890 \mathrm{cdef}$ \\
17 & K3L2M2 & $9,0860 \mathrm{abc}$ \\
18 & K3L2M3 & $9,4217 \mathrm{abc}$ \\
\hline
\end{tabular}

Selama penyimpanan pada masingmasing perlakuan, kadar asam lemak bebas mengalami peningkatan. Hal ini diduga proses hidrolisis sudah terjadi sejak hari ke-0 dan terus berlangsung selama penyimpanan sampai hari ke-30. Dalam reaksi hidrolisis minyak atau lemak akan diubah menjadi asam lemak bebas dan gliserol. Reaksi hidrolisis yang dapat mengakibatkan kerusakan minyak atau lemak terjadi karena adanya sejumlah air dalam minyak dan lemak tersebut.

Menurut Aguilar \& Carvajal-Millan (2019), asam lemak bebas biasanya bergabung dengan lemak netral dan pada konsentrasi $15 \%$ belum menghasilkan flavor yang tidak disenangi. Lemak dengan kandungan asam lemak bebas $1 \%$, jika dicicipi akan membentuk film pada permukaan lidah dan tidak berbau tengik. Menurut Fiorino dkk. (2019), keberadaan asam lemak bebas di dalam minyak dapat mengakibatkan bau yang tidak enak. Hal ini mengakibatkan keberadaannya tidak dikehendaki sehingga diupayakan untuk ditekan sesedikit mungkin. Semakin sedikit kadar asam lemak bebas maka mutu minyak akan semakin baik. Asam lemak bebas walaupun berada dalam jumlah kecil mengakibatkan rasa tidak lezat.

Interaksi terbaik untuk menghambat kadar asam lemak bebas adalah pada Interaksi antara stapler, PP 0,07 mm, dan waktu penyimpanan 10 hari. Interaksi antara ketebalan pengemas dengan waktu penyimpanan memberikan pengaruh yang nyata terhadap kadar asam lemak bebas. Hal tersebut diduga karena semakin tebal suatu kemasan maka permeabilitas terhadap uap air dan gas semakin rendah. Selama penyimpanan, uap air dan gas yang masuk ke dalam kemasan semakin besar sehingga reaksi hidrolisis dan oksidasi terus meningkat.

\section{Uji Organoleptik}

\section{Aroma}

Aroma adalah sesuatu yang dapat diamati dengan indera pembau. Dalam dunia industri bahan pangan, aroma merupakan salah satu faktor yang menentukan mutu suatu produk. Pengujian terhadap aroma dapat dipakai sebagai kriteria dapat diterima atau tidaknya suau produk untuk dipasarkan (Hollowood $d k k$., 2018; Zhong \& Wang, 2019).

Tabel 4. Rataan nilai aroma pada perlakuan penelitian

\begin{tabular}{ccc}
\hline \multirow{2}{*}{ Perlakuan } & \multicolumn{2}{c}{ Aroma } \\
\cline { 2 - 3 } & Rataan & Nilai Friedman \\
\hline K1L1M1 & 2,73 & 147,3 \\
K1L1M2 & 2,27 & 149,5 \\
K1L1M3 & 2,22 & 140,7 \\
K1L2M1 & 2,86 & 161,2 \\
K1L2M2 & 1,92 & 115,7 \\
K1L2M3 & 1,92 & 107,5 \\
K2L1M1 & 2,67 & 142,5 \\
K2L1M2 & 2,46 & 173,8 \\
K2L1M3 & 2,23 & 145,7 \\
K2L2M1 & 2,78 & 142,8 \\
K2L2M2 & 2,17 & 131,2 \\
K2L2M3 & 2,32 & 136,3 \\
K3L1M1 & 2,72 & 140,3 \\
K3L1M2 & 2,42 & 113,0 \\
K3L1M3 & 2,62 & 104,3 \\
K3L2M1 & 2,76 & 145,8 \\
K3L2M2 & 1,96 & 169,5 \\
K3L2M3 & 2,10 & 183,5 \\
\hline Xhitung & & 42,66 \\
Xtabel & & 27,59 \\
\hline
\end{tabular}




\section{Analisis Mutu Keripik Tempe Berdasarkan Cara Perekatan dan Ketebalan Pengemas selama Penyimpanan}

Hasil analisis dengan uji Friedman pada Tabel 4 menunjukkan bahwa aroma keripik tempe secara nyata dipengaruhi oleh kombinasi antara perlakuan jenis perekat, ketebalan pengemas dan waktu penyimpanan. Nilai rata-rata aroma keripik tempe yang dikemas dengan plastik polipropilen $0,07 \mathrm{~mm}$ dengan perekat stapler pada penyimpanan hari ke-10, 20, dan 30 berturut-turut sebesar 2,73 (agak harum-harum), 2,27 (agak harum), dan 2,22 (agak harum); dengan perekat lilin pada penyimpanan hari ke-10, 20, dan 30 berturut-turut sebesar 2,67 (agak harumharum), 2,46 (agak harum-harum), dan 2,23 (agak harum); dengan perekat sealer pada penyimpanan hari ke-10, 20, dan 30 berturut-turut sebesar 2,72 (agak harumharum), 2,42 (agak harum-harum), dan 2,62 (agak harum-harum).

Nilai rata-rata aroma keripik tempe yang dikemas dengan plastik polipropilen 0,04 mm dengan perekat stapler pada penyimpanan hari ke-10, 20, dan 30 berturut-turut sebesar 2,86 (agak harumharum), 1,92 (tidak harum-agak harum), dan 1,92 (tidak harum-agak harum); dengan perekat lilin pada penyimpanan hari ke-10, 20, dan 30 berturut-turut sebesar 2,78 (agak harum-harum), 2,17 (agak harum), dan 2,32 (agak harum); dengan perekat sealer pada penyimpanan hari ke-10, 20, dan 30 berturut-turut sebesar 2,76 (agak harum-harum), 1,96 (tidak harum-agak harum), dan 2,1 (agak harum).

Semakin lama penyimpanan, terjadi penurunan nilai rata-rata aroma keripik tempe. Hal ini diduga karena adanya degradasi minyak yang berakibat pada timbulnya bau tengik. Perlakuan kombinasi jenis plastik polipropilen $0,07 \mathrm{~mm}$ dengan jenis perekat sealer lebih baik dalam mempertahankan aroma keripik tempe dibandingkan dengan perlakuan yang lain. Hal ini diduga karena kombinasi tersebut mampu menjaga kontak dengan lingkungan luar kemasan sehingga aroma keripik tempe dapat terjaga.

\section{Tekstur}

Berdasarkan hasil analisis uji Friedman pada Tabel 5 menunjukkan bahwa kombinasi antara perlakuan jenis perekat, ketebalan pengemas dan waktu penyimpanan memberikan pengaruh yang nyata.

Tabel 5. Rataan nilai tekstur pada perlakuan penelitian

\begin{tabular}{ccc}
\hline \multirow{2}{*}{ Perlakuan } & \multicolumn{2}{c}{ Tekstur } \\
\cline { 2 - 3 } & Rataan & Nilai Friedman \\
\hline K1L1M1 & 3,20 & 141,17 \\
K1L1M2 & 2,98 & 173,17 \\
K1L1M3 & 2,78 & 155,00 \\
K1L2M1 & 3,20 & 133,17 \\
K1L2M2 & 2,32 & 105,30 \\
K1L2M3 & 2,33 & 110,30 \\
K2L1M1 & 3,43 & 160,17 \\
K2L1M2 & 3,00 & 171,50 \\
K2L1M3 & 2,80 & 155,17 \\
K2L2M1 & 3,40 & 148,00 \\
K2L2M2 & 3,00 & 127,50 \\
K2L2M3 & 2,62 & 139,30 \\
K3L1M1 & 3,20 & 136,30 \\
K3L1M2 & 2,91 & 164,17 \\
K3L1M3 & 2,82 & 156,17 \\
K3L2M1 & 3,24 & 142,00 \\
K3L2M2 & 2,50 & 111,33 \\
K3L2M3 & 2,69 & 141,17 \\
\hline Xhitung & & 36,43 \\
Xtabel & & 27,59 \\
\hline
\end{tabular}

Nilai rata-rata tekstur keripik tempe yang dikemas dengan plastik polipropilen 0,07 mm dengan perekat stapler pada penyimpanan hari ke-10, 20, dan 30 berturut-turut sebesar 3,2 (renyah), 2,98 (agak renyah-renyah), dan 2,78 (agak renyah-renyah); dengan perekat lilin pada penyimpanan hari ke-10, 20, dan 30 berturut-turut sebesar 3,34 (renyah), 3 (renyah), dan 2,8 (agak renyah-renyah); 


\section{Analisis Mutu Keripik Tempe Berdasarkan Cara Perekatan dan Ketebalan Pengemas selama Penyimpanan}

dengan perekat sealer pada penyimpanan hari ke- 10, 20, dan 30 berturut-turut sebesar 3,2 (renyah), 2,9 (agak renyahrenyah), dan 2,8 (agak renyah-renyah).

Nilai rata-rata tekstur keripik tempe yang dikemas dengan plastik polipropilen $0,04 \mathrm{~mm}$ dengan perekat stapler pada penyimpanan hari ke-10, 20, dan 30 berturut-turut sebesar 3,2 (renyah), 2,32 (agak renyah), dan 2,33 (agak renyah); dengan perekat lilin pada penyimpanan hari ke-10, 20, dan 30 berturut-turut sebesar 3,4 (renyah), 2,97 (agak renyah32 renyah), dan 2,6 (agak renyah-renyah); dengan perekat sealer pada penyimpanan hari ke-10, 20, dan 30 berturut-turut sebesar 3,24 (renyah), 2,5 (agak renyah), dan 2,67 (agak renyah-renyah).

Data tersebut menunjukkan adanya penurunan tekstur keripik tempe selama penyimpanan. Semakin lama umur simpan keripik tempe, tekstur keripik tempe semakin menurun. Penurunan nilai ratarata tekstur berkaitan dengan kadar air yang terkandung dalam keripik tempe. Semakin lama penyimpanan, uap air yang terserap ke dalam pengemas semakin banyak sehingga tekstur keripik tempe menjadi menurun.

\section{Ketengikan}

Hasil uji Friedman memperlihatkan bahwa kombinasi perlakuan jenis perekat, ketebalan pengemas dan waktu penyimpanan memberikan pengaruh terhadap ketengikan keripik tempe.

Tabel 6. Rataan nilai ketengikan pada perlakuan penelitian

\begin{tabular}{ccc}
\hline \multirow{2}{*}{ Perlakuan } & \multicolumn{2}{c}{ Ketengikan } \\
\cline { 2 - 3 } & Rataan & Nilai Friedman \\
\hline K1L1M1 & 3,56 & 133,00 \\
K1L1M2 & 3,59 & 143,50 \\
K1L1M3 & 3,27 & 137,17 \\
K1L2M1 & 3,62 & 140,00
\end{tabular}

\begin{tabular}{ccc}
\hline \multirow{2}{*}{ Perlakuan } & \multicolumn{2}{c}{ Ketengikan } \\
\cline { 2 - 3 } & Rataan & Nilai Friedman \\
\hline K1L2M2 & 3,32 & 121,67 \\
K1L2M3 & 3,18 & 131,80 \\
K2L1M1 & 3,71 & 149,30 \\
K2L1M2 & 3,75 & 162,10 \\
K2L1M3 & 3,44 & 158,70 \\
K2L2M1 & 3,59 & 138,30 \\
K2L2M2 & 3,80 & 167,17 \\
K2L2M3 & 3,33 & 143,80 \\
K3L1M1 & 3,62 & 153,17 \\
K3L1M2 & 3,55 & 138,17 \\
K3L1M3 & 3,49 & 160,00 \\
K3L2M1 & 3,73 & 140,50 \\
K3L2M2 & 3,50 & 135,00 \\
K3L2M3 & 3,05 & 121,17 \\
\hline Xhitung & & 28,62 \\
Xtabel & & 27,59 \\
\hline
\end{tabular}

Nilai rata-rata ketengikan keripik tempe yang dikemas dengan plastik polipropilen $0,07 \mathrm{~mm}$ dengan perekat stapler pada penyimpanan hari ke-10, 20, dan 30 berturut-turut sebesar 3,56 (tidak tengik), 3,6 (tidak tengik), dan 3,3 (agak tengik-tidak tengik); dengan perekat lilin pada penyimpanan hari ke-10, 20, dan 30 berturut-turut sebesar 3,71 (tidak tengik), 3,74 (tidak tengik), dan 3,44 (agak tengiktidak tengik); dengan perekat sealer pada penyimpanan hari ke-10, 20, dan 30 berturut-turut sebesar 3,62 (tidak tengik), 3,55 (agak tengik-tidak tengik), dan 3,49 (agak tengik-tidak tengik).

Nilai rata-rata ketengikan keripik tempe yang dikemas dengan plastik polipropilen $0,04 \mathrm{~mm}$ dengan perekat stapler pada penyimpanan hari ke-10, 20, dan 30 berturut-turut sebesar 3,62 (tidak tengik), 3,32 (agak engik-tidak tengik), dan 3,18 (agak tengik); dengan perekat lilin pada penyimpanan hari ke-10, 20, dan 30 berturut-turut sebesar 3,59 (tidak tengik), 3,8 (tidak tengik), dan 3,33 (agak tengiktidak tengik); dengan perekat sealer pada penyimpanan hari ke-10, 20, dan 30 berturut-turut 3,73 (tidak tengik), 3,5 (agak 


\section{Analisis Mutu Keripik Tempe Berdasarkan Cara Perekatan dan Ketebalan Pengemas selama Penyimpanan}

\section{tengik-tidak tengik), dan 3,04 (agak tengik).}

Berdasarkan data tersebut diketahui bahwa semua kombinasi perlakuan masih dapat mempertahankan keripik tempe dari ketengikan sampai penyimpanan hari ke30 walaupun terjadi penurunan tetapi penurunan tersebut tidak terlalu besar. Kombinasi perlakuan antara jenis perekat dengan jenis pengemas yang terbaik yaitu plastik polipropilen $0,07 \mathrm{~mm}$ dengan perekat sealer. Hal ini diduga kombinasi ini memiliki permeabilitas udara yang rendah dibandingkan dengan kombinasi perlakuan yang lain. Udara atau oksigen menjadi faktor penyebab kerusakan keripik tempe berupa ketengikan. Hasil kajian lebih baik bila dibandingkan yang dilakukan oleh Sari dkk. (2019) mutu lemak menurun (menimbulkan tengik), didapatkan hasil yang sama semua perlakuan, yaitu $10,7 \%$.

\section{Rasa}

Analisis dalam bidang sensorik membatasi cita rasa sebagai kombinasi rasa dan bau yang diperoleh lewat mulut-mulut dan hidung. Hasil uji Friedman pada Tabel 7 menunjukkan bahwa kombinasi perlakuan antara jenis perekat, ketebalan pengemas dan waktu penyimpanan memberikan pengaruh yang nyata terhadap rasa keripik tempe.

Tabel 7. Rataan nilai rasa keripik tempe pada perlakuan penelitian

\begin{tabular}{ccc}
\hline \multirow{2}{*}{ Perlakuan } & \multicolumn{2}{c}{ Rasa } \\
\cline { 2 - 3 } & Rataan & Nilai Friedman \\
\hline K1L1M1 & 2,91 & 143,83 \\
K1L1M2 & 2,67 & 157,30 \\
K1L1M3 & 2,36 & 138,83 \\
K1L2M1 & 2,93 & 145,83 \\
K1L2M2 & 2,27 & 120,17 \\
K1L2M3 & 2,17 & 120,00 \\
K2L1M1 & 3,00 & 148,00 \\
K2L1M2 & 2,76 & 166,17
\end{tabular}

\begin{tabular}{ccc}
\hline \multirow{2}{*}{ Perlakuan } & \multicolumn{2}{c}{ Rasa } \\
\cline { 2 - 3 } & Rataan & Nilai Friedman \\
\hline K2L1M3 & 2,60 & 163,00 \\
K2L2M1 & 2,78 & 130,30 \\
K2L2M2 & 2,42 & 127,30 \\
K2L2M3 & 2,45 & 146,83 \\
K3L1M1 & 2,91 & 141,50 \\
K3L1M2 & 2,67 & 157,30 \\
K3L1M3 & 2,56 & 159,30 \\
K3L2M1 & 2,96 & 142,17 \\
K3L2M2 & 2,40 & 124,30 \\
K3L2M3 & 2,20 & 126,50 \\
\hline Xhitung & & 29,19 \\
Xtabel & & 27,59 \\
\hline
\end{tabular}

Nilai rata-rata rasa keripik tempe yang dikemas dengan plastik polipropilen 0,07 mm dengan perekat stapler pada penyimpanan hari ke-10, 20, dan 30 berturut-turut sebesar 2,91 (agak enakenak), 2,67 (agak enakenak), dan 2,4 (agak enak); dengan perekat lilin pada penyimpanan hari ke-10, 20, dan 30 berturut-turut sebesar 3 (enak), 2,76 (agak enak-enak), dan 2,6 (agak enak-enak); dan dengan perekat sealer pada penyimpanan hari ke-10, 20, dan 30 berturut-turut sebesar 2,91 (agak enak-enak), 2,7 (agak enakenak), dan 2,55 (agak enak-enak).

Nilai rata-rata rasa keripik tempe yang dikemas dengan plastik polipropilen $0,04 \mathrm{~mm}$ dengan perekat stapler pada penyimpanan hari ke-10, 20, dan 30 berturut-turut sebesar 2,93 (agak enakenak), 2,27 (agak enak), dan 2,13 (agak enak); dengan perekat lilin pada penyimpanan hari ke-10, 20, dan 30 berturut-turut sebesar 2,78 (agak enakenak), 2,42 (agak enak), dan 2,45 (agak enak); dan dengan perekat sealer pada penyimpanan hari ke-10, 20, dan 30 berturut-turut 2,96 (agak enak-enak), 2,4 (agak enak), dan 2,2 (agak enak).

Penurunan rasa ini diduga karena semakin lama umur simpan, semakin banyak terjadi kerusakan pada keripik tempe. Kerusakan-kerusakan tersebut akan 


\section{Analisis Mutu Keripik Tempe Berdasarkan Cara Perekatan dan Ketebalan Pengemas selama Penyimpanan}

mempengaruhi rasa keripik tempe misalnya dengan adanya peningkatan kadar asam lemak bebas. Adanya asam lemak bebas meskipun dalam jumlah sedikit akan mengakibatkan rasa yang tidak enak pada produk (Ketaren, 1986).

Perbedaan rasa pada masing-masing perlakuan diduga karena adanya sifat permeabilitas uap air dan gas serta ketahanan terhadap zat-zat volatile. Hal tersebut mempengaruhi aroma, karena aroma secara langsung mempengaruhi rasa suatu bahan. Semakin meningkat aroma tidak enak maka rasa produk akan semakin menurun dan semakin cepat suatu produk mengalami perubahan aroma, maka semakin cepat terjadi perubahan rasa.

\section{Kesukaan}

Hasil analisis uji Friedman pada Tabel 8 menunjukkan bahwa kombinasi antara perlakuan jenis perekat, ketebalan pengemas dan waktu penyimpanan memberikan pengaruh nyata terhadap tingkat kesukaan panelis.

Tabel 8. Rataan nilai kesukaan pada perlakuan penelitian

\begin{tabular}{ccc}
\hline \multirow{2}{*}{ Perlakuan } & \multicolumn{2}{c}{ Kesukaan } \\
\cline { 2 - 3 } & Rataan & Nilai Friedman \\
\hline K1L1M1 & 2,90 & 145.17 \\
K1L1M2 & 2,60 & 154,83 \\
K1L1M3 & 2,24 & 131,00 \\
K1L2M1 & 2,96 & 151,30 \\
K1L2M2 & 2,16 & 108,83 \\
K1L2M3 & 2.00 & 110,17 \\
K2L1M1 & 2,95 & 144,67 \\
K2L1M2 & 2,73 & 174,30 \\
K2L1M3 & 2,53 & 162,00 \\
K2L2M1 & 2,73 & 132,30 \\
K2L2M2 & 2,38 & 131,67 \\
K2L2M3 & 2,55 & 156,7 \\
K3L1M1 & 2,84 & 137,3 \\
K3L1M2 & 2,60 & 157,5 \\
K3L1M3 & 2,51 & 162,0 \\
K3L2M1 & 2,93 & 142,00 \\
K3L2M2 & 2,40 & 133,33 \\
K3L2M3 & 2,31 & 136,83 \\
\hline
\end{tabular}

\begin{tabular}{|c|c|c|}
\hline \multirow{2}{*}{ Perlakuan } & \multicolumn{2}{|c|}{ Kesukaan } \\
\hline & Rataan & Nilai Friedman \\
\hline Xhitung & & 28,90 \\
\hline Xtabel & & 27,59 \\
\hline
\end{tabular}

Nilai rata-rata kesukaan terhadap keripik tempe yang dikemas dengan plastik polipropilen 0,07 $\mathrm{mm}$ dengan perekat stapler pada penyimpanan hari ke-10, 20, dan 30 berturut-turut sebesar 2,9 (agak suka), 2,6 (agak suka), dan 2,24 (agak suka); dengan perekat lilin pada penyimpanan hari ke-10, 20, dan 30 berturutturut sebesar 2,95 (agak sukasuka), 2,73 (agak suka-suka), dan 2,5 (agak suka); dengan perekat sealer pada penyimpanan hari ke-10, 20, dan 30 berturut-turut sebesar 2,84 (agak sukasuka), 2,6 (agak suka-suka), dan 2,5 (agak suka).

Nilai rata-rata kesukaan terhadap keripik tempe yang dikemas dengan plastik polipropilen 0,04 $\mathrm{mm}$ dengan perekat stapler pada penyimpanan hari ke-10, 20, dan 30 berturut-turut sebesar 2,95 (agak suka-suka), 2,16 (agak suka), dan 2 (agak suka); dengan plastik polipropilen 0,04 $\mathrm{mm}$ dengan perekat lilin pada penyimpanan hari ke-10, 20, dan 30 berturut-turut sebesar 2,73 (agak sukasuka), 2,38 (agak suka), dan 2,55 (agak suka-suka); dengan perekat sealer pada penyimpanan hari ke-10, 20, dan 30 berturut-turut sebesar 2,93 (agak sukasuka), 2,4 (agak suka), dan 2,3 (agak suka). Semakin lama umur simpan keripik tempe penerimaan konsumen semakin menurun. Hal ini diduga karena terjadinya perubahan pada tekstur, aroma, ketengikan dan rasa keripik tempe.

Hasil uji organoleptik selaras dengan hasil kajian Furqon $d k k$. (2016) terhadap uji organoleptik nugget yang menunjukkan bahwa plastik jenis PP mampu mempertahankan rasa, aroma, tekstur dan 
warna nugget dari kerusakan sampai hari ke 20. Menurut Wijayanti \& Purwatiningrum (2016), Cara Produksi Pangan yang Baik (CPPB), dapat menjaga kualitas produk, menjamin keamanan pangan, dan dapat memenuhi permintaan konsumen.

\section{KESIMPULAN}

Kesimpulan penelitian ini yaitu: keripik tempe kemasan plastik polipropilen $0,07 \mathrm{~mm}$ dan perekat sealer mempertahankan mutu terbaik. Selama penyimpanan terjadi peningkatan kadar air, kadar asam lemak bebas, dan terjadi penurunan semua variabel sensorik, tetapi keripik tempe kemasan plastik polipropilen 0,07 mm dengan perekat sealer mampu mempertahankan mutu keripik tempe sampai hari ke-30, sedangkan perlakuan lainnya hanya mampu sampai hari ke-20.

\section{DAFTAR RUJUKAN}

Aguilar, C. N. \& Carvajal-Millan, E. (2019). Applied Food Science and Engineering with Industrial Applications. Toronto: Apple Academic Press.

Alkarkhi, A. F. M. \& Alqaraghuli, W. A. A. (2019). Easy Statistics for Food Science with R. London: Academic Press.

Barus, T., Wati, L., Melani, Suwanto, A., $\&$ Yogiara. (2017). Diversity of Protease-Producing Bacillus spp. From Fresh Indonesian Tempeh Based on 16S rRNA Gene Sequence. Hayati Journal of Biosciences, 24(1), 35-40, doi.org/10.1016/j.hjb.2017.05.001, https://www.sciencedirect.com/scien ce/article/pii/S1978301916300390

Bernaldo de Quirós, A. R., Cardama, A. L., Sendón, R., \& Ibarra, V.G. (2019). Food Contamination by Packaging: Migration of Chemicals from Food
Contact Materials. Berlin: Walter de Gruyter GmbH.

Cirillo, G., Kozlowski, M. A., \& Spizzirri, U.G. (2018). Composites Materials for Food Packaging. New Jersey: Scrivener Publishing LLC.

Duan, C., Fang, Y., Sun, J., Li, Z., Wang, Q., Bai, J., Peng, H., Liang, J., \& Gao, Z. (2020). Effects of Fast Food Packaging Plasticizers and Their Metabolites on Steroid Hormone Synthesis in H295R Cells. Science of The Total Environment, 726(15), 138500 ,

doi.org/10.1016/j.scitotenv.2020.138 500 ,

https://www.sciencedirect.com/scien ce/article/pii/S0048969720320131

Erkan, S. B., Gürler, H. N., Bilgin, D. G., Germec, M., \& Turhan, I. (2020). Production and Characterization of Tempehs from Different Sources of Legume by Rhizopus Oligosporus. LWT-Food Science and Technology, 119(2), 108880 , doi.org/10.1016/j.lwt.2019.108880, https://www.sciencedirect.com/scien ce/article/pii/S0023643819312228

Fiorino, M., Barone, C., Barone, M., Mason, M., \& Bhagat, A. (2019). Quality Systems in the Food Industry. Switzerland: Springer International Publishing.

Furqon, A. A. Q., Maflahah, I., \& Rahman, A. (2016). Pengaruh Jenis Pengemas dan Lama Penyimpanan Terhadap Mutu Produk Nugget Gembus. Agrointek, 10(2), 71-76, https://doaj.org/article/294d2fe43f7c 44c69175a460ede316c1

Grumezescu, A. M. \& Holban, A. M. (2018). Food Packaging and Preservation. London: Academic Press.

Herawati, E. R. N., Nurhayati, R., Angwar, M., \& Wakhida, V. (2017). Pendugaan Umur Simpan Keripik Pisang Salut Cokelat "Purbarasa" Kemasan Polipropilen berdasarkan Angka TBA dengan Metode Aslt 
Model Arrhenius. Reaktor. 17(3), 118-125, doi: 10.14710/reaktor.17.3.118-125, https://doaj.org/article/e66b292c2141 4f3690fe8747b41f8a13

Hollowood, T., Hort, J., \& Kemp, S.E. (2018). Descriptive Analysis in Sensory Evaluation. New Jersey: John Wiley \& Sons.

Huang, L., Huang, Z., Zhang, Y., Zhou, S., Hu, W., \& Dong, M. (2019). Impact of Tempeh Flour on the Rheology of Wheat Flour Dough and Bread Staling. LWT-Food Science and Technology, 111(8), 694-702, doi.org/10.1016/j.lwt.2019.04.004, https://www.sciencedirect.com/scien ce/article/pii/S0023643819303007

Jariyah, Mulyani T. S., Sudaryati, H. P., \& Rekapangan, $\mathrm{S}$. (2015). Pengembangan Usaha Kelompok Perajin Tempe di Kecamatan Candi Kabupaten Sidoarjo. Jurnal Teknologi Pangan, 8(2), doi: 10.33005/jtp.v8i2.456, https://doaj.org/article/a0fd57f66662 44d7b498e7ae07483d98

Kurniawati, S., Lestiani, D. D., Damastuti, E., \& Santoso, M. (2019). The Selenium Content of Tempeh in Indonesia and its Potential Contribution to the Dietary Selenium Requirements for Adults. Journal of Food Composition and Analysis, 82(9), 103222 , doi.org/10.1016/j.jfca.2019.05.005, https://www.sciencedirect.com/scien ce/article/abs/pii/S088915751830491 $\underline{5}$

Marcus, J. B. (2019). Aging, Nutrition and Taste: Nutrition, Food Science and Culinary Perspectives for Aging Tastefully. London: Academic Press.

Meilgaard, M. C., Civille, G. V., \& Carr, B.T. (2016). Sensory Evaluation Techniques. Boca Raton: CRC Press. Mindarti, L. I. (2016). Peningkatan Daya Saing UMKM Perempuan melalui Comparative Advantage: Study pada UMKM “Keripik Tempe Rohani” di
Sentra Keripik Sanan, Kota Malang. Kafa'ah: Journal of Gender Studies, 6(1), 1-12, doi: 10.15548/jk.v6i1.135, https://doaj.org/article/c150ff40ca60 49f2983f54bd5b288128

Nielsen, S. S. (2017). Food Analysis Laboratory Manual. Switzerland: Springer International Publishing.

Piergiovanni, L. \& Limbo, S. (2016). Food Packaging Materials. New York: Springer International Publishing.

Roreng, M. K., Sarungallo, Z. L., Murtiningrum, M., Santoso, B., \& Latumahina, R. M. M. (2016). Mutu Mikrobiologis Drupa Buah Merah (Pandanus conoideus Lamk.) pada Berbagai Jenis Kemasan selama Penyimpanan. Agrointek, 10(2), 9399,

https://doaj.org/article/0cfb0dd7661e 4b858d50c2c7a25baffo

Sari, H. M., Yosephin, B., \& Haya, M. (2019). Variasi Pengolahan Daya Terima dan Kandungan Zat Gizi Keripik Tempe Rasa Bawang. AcTion: Aceh Nutrition Journal, 4(1), 1-6, doi: 10.30867/action.v4i1.108, https://doaj.org/article/7347b97999ef 4a4187bb982d06a2c7ea

Shockey, K. K., \& Shockey, C. (2019). Miso, Tempeh, Natto \& Other Tasty Ferments: A Step-by-Step Guide to Fermenting Grains and Beans. North Adams: Storey Publishing, LLC.

Shurtleff, W. \& Aoyagi, A. (2001), The Book of Tempeh. California: Ten Speed Press.

Singh, P., Wani, A. A., \& Langowski, H. C. (2017). Food Packaging Materials: Testing \& Quality Assurance. Boca Raton: CRC Press.

Warsiki, E. \& Damanik, M. R. (2012). Perubahan Mutu dan Umur Simpan Sup Daun Torbangun (Colues Amboinicus Lour) dalam Kemasan. Jurnal Gizi dan Pangan, 7(1), https://doaj.org/article/07286f996041 473b9f65dead9f94fa80. 
Wijayanti, N. \& Purwantiningrum, I. (2016). Peningkatan Efisiensi dan Kapasitas Produksi pada Proses Pengolahan Sambel Pecel, Keripik Tempe dan Keripik Singkong. Teknologi Pangan: Media Informasi dan Komunikasi Ilmiah Teknologi Pertanian, 7(3), doi: 10.35891/tp.v7i3.518, https://doaj.org/article/c199432b512f 4644b2f03889094fcd0a

Zhong, J. \& Wang, X. (2019). Evaluation Technologies for Food Quality. Cambridge: Woodhead Publishing. 